\title{
Gastrointestinal parasitic infections of buffaloes (Bubalus bubalis) in Sarawak Borneo: Prevalence, risk factors, and farming practices
}

\author{
Harizt, A.M. ${ }^{1}$, Malahubban, M. ${ }^{1}$, Syed-Hussain, S.S. ${ }^{2}$, Ramanoon, S.Z. ${ }^{3}$, Sadiq, M.B. ${ }^{3}$, Sarbini, S.R. ${ }^{1}$, \\ Hassan, M.N. ${ }^{1}$, Mustafa, S. ${ }^{1}$, Aziz, N.A.A. ${ }^{4}$, Isa, N.M.M. ${ }^{4}$, Nating, W.R. ${ }^{5}$, Asut, R. ${ }^{5}$, Kamaludeen, J. ${ }^{{ }^{*}}$ \\ ${ }^{1}$ Department of Animal Science and Fishery, Faculty of Agriculture Science and Forestry, Universiti Putra Malaysia Bintulu Sarawak Campus, \\ 97008 Bintulu, Sarawak, Malaysia \\ ${ }^{2}$ Department of Veterinary Clinical Studies, Faculty of Veterinary Medicine, Universiti Putra Malaysia, 43400 Serdang, Selangor, Malaysia \\ ${ }^{3}$ Department of Farm and Exotic Animal Medicine and Surgery, Faculty of Veterinary Medicine, University Putra Malaysia, 43400 Serdang, Selangor, \\ Malaysia \\ ${ }^{4}$ Department of Veterinary Pathology \& Microbiology, Faculty of Veterinary Medicine, Universiti Putra Malaysia, 43400 Serdang, Selangor, Malaysia \\ ${ }^{5}$ Department of Veterinary Services Sarawak, Kuching, Sarawak, Malaysia \\ *Corresponding author: juriahk@upm.edu.my
}

\section{ARTICLE HISTORY}

Received: 22 March 2021

Revised: 30 June 2021

Accepted: 1 July 2021

Published: 30 August 2021

\begin{abstract}
The objectives of this study were to investigate the prevalence and associated risk factors for gastrointestinal (GI) parasites in buffaloes from various areas of Sarawak, and to assess current management practices of GI parasites among farmers. Faecal samples were collected from 15 farms and 129 animals, as well as data on farm and animal-based characteristics. A total of 129 faecal samples were examined for GI parasites using a modified McMaster and sedimentation. Association between potential risk factors and the prevalence of GI parasites was investigated using Chi-square statistic. The prevalence of Paramphistomum sp., strongyles, and coccidia were $75.2 \%$ (95\% $\mathrm{Cl} \pm 7.5), 52.7 \%(95 \% \mathrm{Cl} \pm 8.6)$ and $48.1 \%(95 \% \mathrm{Cl} \pm 8.6)$, respectively. Farms which had a grazing area less than 50 acres in size had significantly higher prevalence of strongyles $\left(70.5 \%, \chi^{2}=8.34, \mathrm{P}=0.004\right)$ and paramphistomes $\left(88.6 \%, \chi^{2}=6.46, \mathrm{P}=0.01\right)$ relative to farms with a larger grazing area ( $43.5 \%$ and $68.2 \%$, respectively). Prevalence of strongyles was lower in farms that did not implement a cut- and-carry system $\left(45.6 \%, \chi^{2}=\right.$ $4.17, \mathrm{P}=0.04)$ in comparison to those that did $(64 \%)$. The prevalence of paramphistomes was higher on farms with more than 40 animals $\left(80.6 \%, \chi^{2}=3.18, P=0.05\right)$ relative to farms with fewer animals. The majority of farmers surveyed (67.9\%) showed awareness of GI parasite infection and reported that they recognized the associated symptoms. Most farmers practised deworming, and ivermectin was the most commonly used anthelminthic (60.4\%); only $1.9 \%$ of farmers used albendazole. Overall this study revealed a high prevalence of GI parasites in buffalo in Sarawak. Although farmers report they are aware of parasitic diseases, further education is still required. This could include how they can successfully implement on-farm changes to reduce the prevalence of GI parasites in their herds.
\end{abstract}

Keywords: Buffalo; gastrointestinal parasites; risk factors; farmers; Sarawak.

\section{INTRODUCTION}

Gastrointestinal (GI) parasites are ubiquitous and they contribute significantly to reduced productivity in the buffalo industry (Gorsich et al., 2014). The effects of GI parasites on their hosts are related to the depletion of host resources through reduced intestinal function (Stewart \& Penzhorn, 2004), or limiting the capacity of the host to control coinfecting parasites (Gorsich et al., 2014). Such effects are manifested at different degrees depending on the immune status and immune response of the host (Graham-Brown et al., 2018). Economic losses in the buffalo industry, particularly in smallholder farming systems, have also been attributed to the deleterious effects of GI parasites (Raza et al., 2007). However, the precise economic impact of these infections is unknown.

Parasitism is considered to be the second most significant disease in Malaysia's livestock industry with high morbidity and mortality (Nor-Azlina et al., 2011). The commonly reported parasites in buffaloes include strongyles (Karim et al., 2016; Nurhidayah et al., 2019), Trichuris sp., Moniezia sp., Toxocara vitulorum (Dorny et al., 2015; Gunathilaka et al., 2018), and Theileria sp. (Rohaya et al., 2017); as well as trematodes such as Fasciola gigantica (Das et al., 2018; Zhang et al., 2019), Paramphistomes (Gunathilaka et al., 2018) and Gigantocotyle explanandum (Malik et al., 2017). The 
Malaysian water buffalo, Bubalus bubalis is an important component of livestock production for the inhabitants of Borneo Sarawak. Most buffalo farmers in Sarawak practice extensive management systems. Buffaloes often co-graze with other species and this may increase their exposure to parasitic helminths. However, several studies have stated that a deeper understanding of feeding behaviour and the potential for cross-nematode species transmission could provide a better comprehension of the host-parasite relationship (Hoste et al., 2010; Moco et al., 2014).

Currently, there is no available data on Gl parasitic infections and associated risk factors in Malaysian water buffalo, as most of the previously published studies were conducted in cattle and goats (Chandrawathani et al., 2009; Nor-Azlina et al., 2011; Basripuzi et al., 2012). Furthermore, there is limited data on the socio-demographics of buffalo farmers, as well as herd health control strategies and specific management practices used by these farmers to manage $\mathrm{GI}$ parasites of buffaloes in Sarawak. The present study was designed to investigate, 1 ) the prevalence of GI parasites in buffalo located in the major buffalo rearing areas of Sarawak, namely Bintulu, Limbang, and Lawas, 2) describe the sociodemographic characteristics, knowledge, and management practices of GI parasites of buffalo farmers in these areas.

\section{MATERIALS AND METHODS}

\section{Study design, sample size estimation and sampling protocol}

A cross-sectional study was conducted involving buffalo farms in Bintulu, Lawas, and Limbang between October 2017 and May 2019 (Figure 1). These locations were selected since $86 \%(5,500)$ of the buffalo in Sarawak are located within these regions. The farmers' details were provided by the Department of Veterinary Service (DVS), Sarawak. On initial contact, the farmers were briefed about the study objectives and the inclusion criteria. The inclusion criteria included, 1) animals should not have been treated with anthelmintics for at least 3 months prior to sampling, 2) farms were required to have up to date records on animal health, 3) the farm should be registered with the DVS, and 4) farmers should be available during the scheduled time for farm visits. A total of 15 farms fulfilled the inclusion criteria and were enrolled in the study. Only one farm agreed to participate in Bintulu.

\section{Farm and animal assessment}

Information was collected regarding the characteristics of the farm including: management system, the number of pens, herd size, the number of adult and young animals, size of wallowing area and grazing area, source of livestock, deworming practices, method of feed preparation, and the source of feed. The sex, breed, and age of the animals were recorded. Domestic water buffalo are classified into two different types: swamp ('Kerbau Sawah') and river ('Murrah') buffalo. Swamp buffaloes are mainly used for labour and are raised for meat purposes, whereas Murrah buffaloes are used for milk production. Buffaloes were classified by age as either calf (less than 1 year), adults (1-5 years), or old (more than 5 years).

The buffaloes from Limbang and Lawas were owned by smallholder farmers who had small herd sizes, ranging from two to 16 animals. Farms from these regions mainly practiced extensive management systems. In Bintulu, only one farm fulfilled the inclusion criteria. The buffaloes at this farm

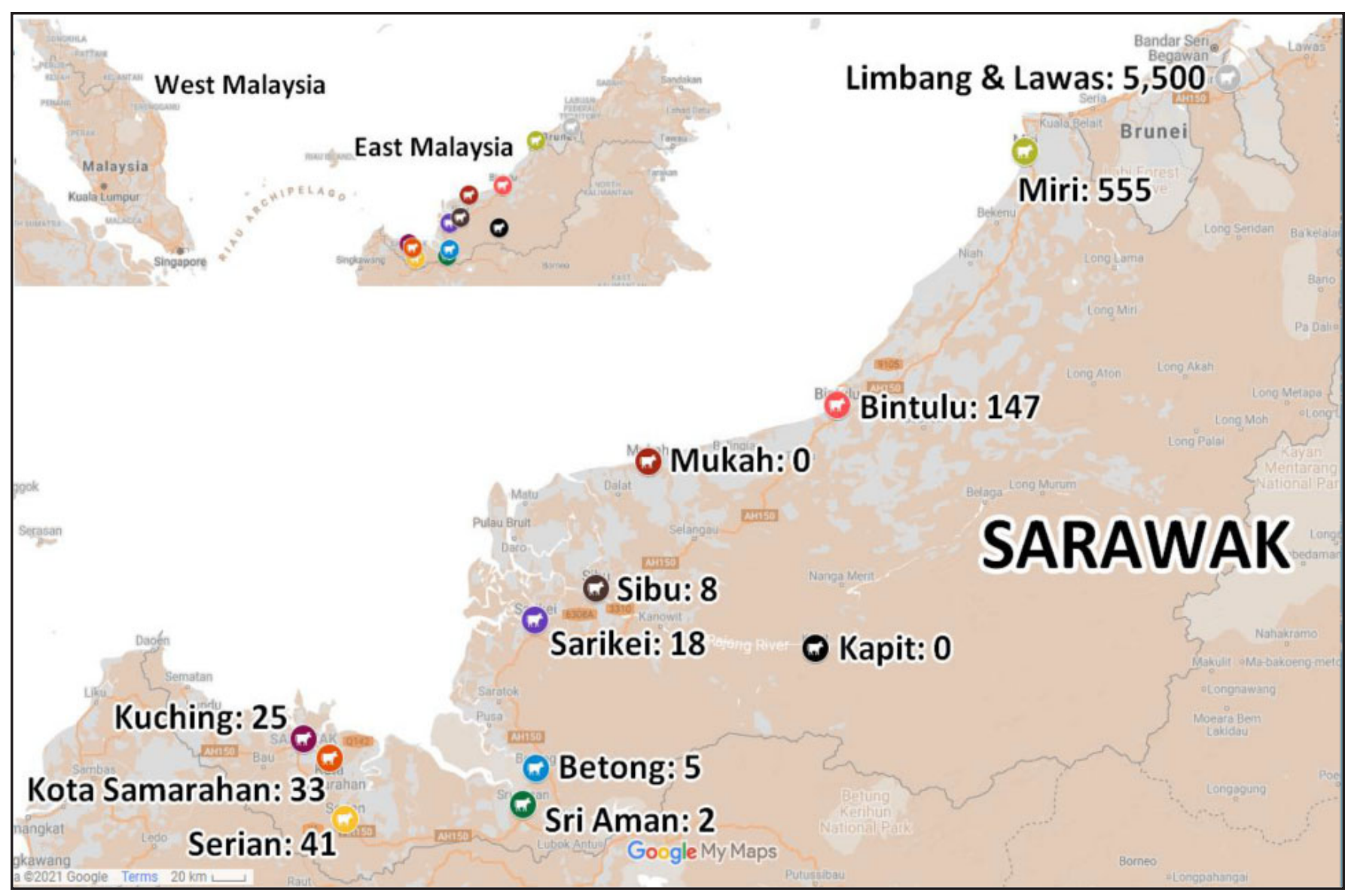

Figure 1. Distribution of buffalo in Borneo Sarawak, East Malaysia, 2020 (Source: Department of Veterinary Services, DVS). 
were managed semi-intensively and provided with grazing areas at the University Agriculture Park (Livestock Unit) all year round. The animals were fed using a 'cut-and-carry' feeding system which entailed the harvest and preparation of Napier grass within given farmland.

\section{Sampling of animals}

On farms with large herd sizes, animals were randomly selected from the different pens. If a farm had more than one pen, an equal number of animals were sampled from each. Sampling was conducted to reflect the proportion of adult and young animals in each herd. In farms with less than 10 buffaloes, all animals were sampled.

Each animal was immobilized in a standing position and a single researcher collected the faecal samples per rectum using a clean, gloved hand (Jolles et al., 2008). Faecal samples were transferred to a sampling bottle and labelled. Samples were stored in iceboxes and transported to the office (20 to 45 minutes distance) where they were then stored at $4^{\circ} \mathrm{C}$. After completion of each sampling session (3 to 4 days), the faecal samples were stored in iceboxes and transported to the laboratory which took approximately 9 hours and refrigerated at $4^{\circ} \mathrm{C}$ until analysis. The time between sampling animals and testing at the laboratory ranged from 1 to 2 weeks.

\section{Parasitological techniques}

Faecal oocyst/egg counts were performed at the Parasitology Laboratory, Faculty of Agriculture Science and Forestry, Universiti Putra Malaysia, Bintulu, Sarawak. A modified McMaster technique was used to perform the oocyst and egg count (Kamaludeen et al., 2010). The results were recorded as strongyle eggs per gram of feces (epg) or coccidia oocysts per gram of feces (opg). Approximately $2 \mathrm{~g}$ of feces were used to determine the number of oocysts and nematode eggs. For trematodes (i.e., flukes), approximately $5 \mathrm{~g}$ of feces was analysed using a sedimentation technique as described by Kamaludeen et al. (2019). Parasite intensity and infection burden were evaluated based on the counts of nematode or trematode eggs and coccidia oocysts (Ezenwa \& Jolles, 2008; Gorsich et al., 2014).

\section{Questionnaire design and administration}

A structured questionnaire was developed to assess farmer demographics, current management practices, and knowledge of GI parasites. To assist design we (1) reviewed previous surveys of buffalo farmers that focuses on health and welfare management, (2) we reviewed specific practices relating to buffalo farming in the Malaysian context to ensure the questionnaire was appropriate, and (3) the questionnaire was assessed by staff from the DVS Sarawak.

The questionnaire was split into three sections and comprised of 27 questions. The first section focused on the demographics of the farmers. The second section was about farm details and management practices, and included questions on the size of the farm, animal feed, water sources, herd size, and management system. The final section collected information on health management such as control of parasitic infection, use of anthelminthic drugs, deworming practices, and also included questions to assess farmers' knowledge of the symptoms of parasitic infections in animals.

The registry list provided by the DVS Sarawak were used to contact buffalo farmers within the study location. A total of 150 farmers that were registered with the DVS were contacted to participate in the survey. Each farmer was informed about the purpose of the study, methodology, confidentiality of all information provided, and their voluntary consent to take part in the survey. Fifty-three (35\%) of the farmers agreed to take part. They were asked to sign a consent form, and then complete the questionnaire.

\section{Data analysis}

All statistical analyses were conducted using IBM SPSS (version 23.0). A Kolmogorov-Smirnov normality test was conducted for the dependent (prevalence of GI parasites and coinfection) and independent variables (age, sex, breed, and location) to determine the appropriate descriptive statistic (mean and standard deviation, or median and interquartile range).

The prevalence of each parasite was computed using descriptive statistics. Chi-square statistics were used to determine the univariate associations between potential risk factors (i.e., animal and farm factors) and the prevalence of strongyles, coccidia, paramphistomes, and co-infection. A P-value less than 0.05 was considered significant. Since only one farm was sampled from Bintulu, the association between farm location and prevalence of parasitic infection was only calculated for farms in Limbang and Lawas.

Data from the completed questionnaires were inputted into Microsoft Excel, before transfer to the statistical software. Descriptive statistics were used to analyse the responses based on the socio-demographic characteristics of farmers, management practises, and their knowledge on the effect of $\mathrm{Gl}$ parasites to buffalo.

\section{RESULTS}

\section{Prevalence and intensity of GI parasites}

A total of 129 faecal samples were collected from Limbang, Lawas, and Bintulu District. The majority of the sampled buffaloes were swamp type (83.7\%) with fewer Murrah buffaloes (16.3\%) sampled. Three parasitic species were identified: Paramphistomum sp. with egg counts ranged from 0 to 1440 epg, coccidia oocyst counts ranged from 0 to 500 opg, and Strongyle sp. egg counts ranged from 0-250 epg (Table 1). The highest prevalence across all farms was Paramphistomum sp. (75.2\%). Co-infection with multiple GI parasites was seen at nine farms (Table 1). Only one farm showed no evidence of GI parasitic infection (Farm 3; Table 1).

\section{Factors associated with the prevalence of strongyle, coccidia and paramphistomes}

Farms with a grazing area less than 50 acres had significantly higher prevalence of strongyles $\left(70.5 \%, \chi^{2}=8.34\right.$, degree of freedom $[\mathrm{df}]=1, \mathrm{P}=0.004$ ) than farms where the grazing area was more than 50 acres (43.5\%; Table 2). There was a lower prevalence of strongyles on farms that did not practise the cut-and carry-systems $\left(45.6 \%, \chi^{2}=4.17, \mathrm{P}=0.04\right)$ compared to those that did (64\%; Table 2).

Buffaloes from Limbang had a lower prevalence of paramphistomes $\left(56.1 \%, \chi^{2}=8.7, \mathrm{df}=1, \mathrm{P}=0.003\right)$ that those from Lawas. Farms with a grazing area less than 50 acres in size had significantly higher prevalence of paramphistomes (88.6\%, $\chi^{2}=6.46, \mathrm{df}=1, \mathrm{P}=0.01$ ) relative to farms with more than 50 acres $(68.2 \%)$. Similarly farms with more than 40 animals also had significantly higher prevalence of paramphistomes $\left(80.6 \%, \chi^{2}=3.18, \mathrm{P}=0.05\right)$ than farms with less than 40 animals.

None of the animal factors was significantly associated with the prevalence of any of the GI parasites. The prevalence of co-infection was higher in farms engaging in selfacquisition of livestock $\left(58.7 \%, \chi^{2}=4.09\right.$, df $=1, P=0.04$ ) 
Table 1. Animals positive with infection, prevalence of strongyle, coccidia, Paramphistomum sp. and co-infections of parasitic infections (\%, $95 \% \mathrm{Cl}$ ); egg/oocytes counts (Mean \pm SE) from 15 buffalo farms in Bintulu, Limbang and Lawas, Sarawak, Malaysia

\begin{tabular}{|c|c|c|c|c|c|c|c|c|c|}
\hline \multirow[b]{2}{*}{ Division } & \multirow[b]{2}{*}{ Farm ID } & \multirow{2}{*}{$\begin{array}{c}\mathrm{n} \\
\text { (positive } \\
\text { animals) }\end{array}$} & \multicolumn{6}{|c|}{ Percentage $(95 \% \mathrm{Cl})$ of each species; EPG/OPG range (Mean \pm SE) } & \multirow[b]{2}{*}{ Co-infection } \\
\hline & & & Strongyle & $\begin{array}{l}\text { EPG range } \\
\text { (Mean } \pm S E)\end{array}$ & Coccidia & $\begin{array}{l}\text { OPG range } \\
\text { (Mean } \pm S E \text { ) }\end{array}$ & $\begin{array}{c}\text { Paramphistomum } \\
\text { sp. }\end{array}$ & $\begin{array}{c}\text { EPG range } \\
\text { (Mean } \pm S E)\end{array}$ & \\
\hline Bintulu & $\begin{array}{l}\text { Teaching } \\
\text { farm }\end{array}$ & $12(12)$ & $\begin{array}{c}91.7 \\
( \pm 15.7)\end{array}$ & $\begin{array}{c}0-200 \\
(83.3 \pm 14.2)\end{array}$ & $\begin{array}{l}75.0 \\
(24.5)\end{array}$ & $\begin{array}{c}0-150 \\
(54.2 \pm 13.0)\end{array}$ & $100.0(-)$ & $\begin{array}{c}219-634 \\
(452.8 \pm 40.4)\end{array}$ & $66.7(26.7)$ \\
\hline \multirow[t]{5}{*}{ Limbang } & Farm 1 & $9(4)$ & $\begin{array}{c}33.3 \\
( \pm 30.8)\end{array}$ & $\begin{array}{c}0-100 \\
(22.2 \pm 12.1)\end{array}$ & $\begin{array}{c}22.2 \\
( \pm 27.2)\end{array}$ & $\begin{array}{c}0-50 \\
(16.7 \pm 11.8)\end{array}$ & $11.1( \pm 20.5)$ & $\begin{array}{c}0-233 \\
(25.9 \pm 25.9)\end{array}$ & $0(-)$ \\
\hline & Farm 2 & $5(1)$ & $\begin{array}{c}20.0 \\
( \pm 35.1)\end{array}$ & $\begin{array}{c}0-150 \\
(30.0 \pm 30.0)\end{array}$ & $0(-)$ & 0 & $0(-)$ & 0 & $0(-)$ \\
\hline & Farm 3 & $5(0)$ & $0(-)$ & 0 & $0(-)$ & 0 & $0(-)$ & 0 & $0(-)$ \\
\hline & Farm 4 & $6(6)$ & $\begin{array}{c}50.0 \\
( \pm 40.0)\end{array}$ & $\begin{array}{c}0-50 \\
(25.0 \pm 11.2)\end{array}$ & $\begin{array}{c}6.7 \\
( \pm 37.8)\end{array}$ & $\begin{array}{c}0-500 \\
(125.0 \pm 78.3)\end{array}$ & $6.7( \pm 12.6)$ & $\begin{array}{c}21-820 \\
(240.7 \pm 121.4)\end{array}$ & $50.0( \pm 40.0)$ \\
\hline & Farm 5 & $16(16)$ & $\begin{array}{c}56.3 \\
( \pm 24.4)\end{array}$ & $\begin{array}{c}0-100 \\
(37.9 \pm 9.7)\end{array}$ & $\begin{array}{c}30.0 \\
( \pm 23.7)\end{array}$ & $\begin{array}{c}0-150 \\
(56.3 \pm 14.3)\end{array}$ & $100.0(-)$ & $\begin{array}{c}154-544 \\
(346.6 \pm 30.2)\end{array}$ & $43.8( \pm 24.4)$ \\
\hline \multirow[t]{9}{*}{ Lawas } & Farm 6 & $15(3)$ & $\begin{array}{c}13.3 \\
( \pm 17.2)\end{array}$ & $\begin{array}{c}0-100 \\
(13.3 \pm 9.1)\end{array}$ & $\begin{array}{c}40.0 \\
( \pm 12.6)\end{array}$ & $0-50(3.3 \pm 3.3)$ & $100.0(-)$ & $\begin{array}{c}0-258 \\
(17.2 \pm 17.2)\end{array}$ & $0(-)$ \\
\hline & Farm 7 & $7(7)$ & $\begin{array}{c}80.0 \\
( \pm 24.8)\end{array}$ & $\begin{array}{c}0-250 \\
(105.0 \pm 28.3)\end{array}$ & $\begin{array}{c}66.7 \\
( \pm 28.4)\end{array}$ & $\begin{array}{c}0-150 \\
(30.0 \pm 17.0)\end{array}$ & $100.0(-)$ & $\begin{array}{c}136-1440 \\
(466.0 \pm 139.6)\end{array}$ & $30.0( \pm 28.4)$ \\
\hline & Farm 8 & $10(10)$ & $\begin{array}{c}50.0 \\
( \pm 14.0)\end{array}$ & $\begin{array}{c}0-250 \\
(40.0 \pm 24.5)\end{array}$ & $\begin{array}{c}90.0 \\
( \pm 30.4)\end{array}$ & $\begin{array}{c}0-150 \\
(30.0 \pm 15.3)\end{array}$ & $100.0(-)$ & $\begin{array}{c}120-693 \\
(339.0 \pm 51.5)\end{array}$ & $20.0( \pm 24.8)$ \\
\hline & Farm 9 & $10(10)$ & $\begin{array}{c}77.8 \\
( \pm 27.2)\end{array}$ & $\begin{array}{c}0-200 \\
(83.3 \pm 25.0)\end{array}$ & $\begin{array}{c}66.7 \\
( \pm 30.8)\end{array}$ & $\begin{array}{c}0-200 \\
(72.2 \pm 25.2)\end{array}$ & $100.0(-)$ & $\begin{array}{c}23-934 \\
(500.1 \pm 101.9)\end{array}$ & $55.6( \pm 32.5)$ \\
\hline & Farm 10 & $10(10)$ & $\begin{array}{c}60.0 \\
( \pm 30.4)\end{array}$ & $\begin{array}{c}0-100 \\
(35.0 \pm 10.7)\end{array}$ & $\begin{array}{c}62.5 \\
( \pm 18.6)\end{array}$ & $\begin{array}{c}0-100 \\
(60.0 \pm 10.0)\end{array}$ & $100.0(-)$ & $\begin{array}{c}91-541 \\
(311.4 \pm 39.0)\end{array}$ & $50.0( \pm 31.0)$ \\
\hline & Farm 11 & $8(8)$ & $\begin{array}{c}62.5 \\
( \pm 33.5)\end{array}$ & $\begin{array}{c}0-100 \\
(37.9 \pm 12.5)\end{array}$ & $\begin{array}{c}87.5 \\
( \pm 22.9)\end{array}$ & $\begin{array}{c}0-100 \\
(56.3 \pm 14.8)\end{array}$ & $100.0(-)$ & $\begin{array}{c}198-884 \\
(518.4 \pm 19.1)\end{array}$ & $37.5( \pm 33.5)$ \\
\hline & Farm 12 & $10(10)$ & $\begin{array}{c}70.0 \\
( \pm 28.4)\end{array}$ & $\begin{array}{c}0-100 \\
(50.0 \pm 12.9)\end{array}$ & $\begin{array}{c}50.0 \\
( \pm 31.0)\end{array}$ & $\begin{array}{c}0-150 \\
(40.0 \pm 16.3)\end{array}$ & $100.0(-)$ & $\begin{array}{c}169-683 \\
(347.8 \pm 46.7)\end{array}$ & $30.0( \pm 28.4)$ \\
\hline & Farm 13 & $2(2)$ & $\begin{array}{c}50.0 \\
( \pm 50.0)\end{array}$ & $\begin{array}{c}0-50 \\
(25.0 \pm 25.0)\end{array}$ & $\begin{array}{c}50.0 \\
( \pm 50.0)\end{array}$ & $\begin{array}{c}0-50 \\
(25.0 \pm 25.0)\end{array}$ & $100.0(-)$ & $\begin{array}{c}21-953 \\
(487.0 \pm 466.0)\end{array}$ & $0(-)$ \\
\hline & Farm 14 & $2(2)$ & $0(-)$ & 0 & $\begin{array}{c}50.0 \\
( \pm 50.0)\end{array}$ & $\begin{array}{c}0-150 \\
(75.0 \pm 75.0)\end{array}$ & $100.0(-)$ & $\begin{array}{c}127-358 \\
(242.5 \pm 115.5)\end{array}$ & $0(-)$ \\
\hline $\begin{array}{l}\text { Mean } \\
\text { (\%) / } \\
\text { Total }\end{array}$ & 15 farms & $129(103)$ & $52.7 \pm 8.6$ & $\begin{array}{c}0-250 \\
(44.2 \pm 5.0)\end{array}$ & $48.1 \pm 8.6$ & $\begin{array}{c}0-500 \\
(41.9 \pm 5.7)\end{array}$ & $75.2 \pm 7.5$ & $\begin{array}{c}0-1440 \\
(292.0 \pm 23.6)\end{array}$ & $30.2 \pm 7.9$ \\
\hline
\end{tabular}

$\mathrm{n}=$ number of animals sampled

compared to those assisted by DVS, and farms practising cut-and carry-system $\left(62.0 \%, \chi^{2}=5.01, \mathrm{df}=1, \mathrm{P}=0.02\right)$ relative to farms not practising this system.

Buffalo farming in Sarawak: characteristics and management practises assessed by questionnaire

There was a regional variation in the survey response rates, as most of the responses were from farmers in Lawas (44/53; $83 \%)$. Only eight responses were from farmers in Limbang $(15.1 \%)$, and there was only one response from Bintulu (Table 3).

The majority of the farmers were male $(77.4 \%)$ compared to females (3.8\%, Table 3 ). Most of the respondents were above 60 years old $(52.8 \%)$ and only $11.3 \%$ were below 50 years old. Most of the respondents were full-time farmers $(60.4 \%)$ and $73.6 \%$ had more than 20 years of experience working in the buffalo farming industry. However, it can be noted that the results in Table 3 shows missing data. This was unavoidable as farmers declined to answer some of the questions, this was due to the sensitivity of the questions and an unwillingness to provide such information.

The majority of respondents (90.6\%) practised an extensive management system and depended mostly on grazing natural pastures. Seventy per cent of the participants raised their buffaloes for replacement, whereas $7.5 \%$ of them obtained their buffalo from overseas. The herd size of most of the respondents $(86.8 \%)$ was either less than or equal to 30 buffaloes, and $96.2 \%$ of them had land sizes ranging from 0 to 200 acres. The main source of drinking water for animals on the farms was from streams (67.9\%) (Table 3).

Ivermectin was the most frequently used anthelminthic $(60.4 \%)$, whilst only $1.9 \%$ of the respondents used albendazole (Table 3 ). The majority of respondents (67.9\%) were aware of helminth infection in their animals, and they were familiar with associated symptoms. However, only half of the respondents believed that parasite infection occurs mostly in calves, whereas $20.7 \%$ of them thought that adults were more susceptible to GI parasites.

\section{DISCUSSION}

Little is known about GI parasite infections in livestock from Borneo Island, therefore our findings serve to describe the importance of such infections in buffalo in the studied locations. We identified high prevalence of all the parasites studied: strongyles, coccidia and Paramphistomum sp.; indeed on ten of the fifteen farms we visited every animal sampled was positive for at least one of these groups of parasites. 


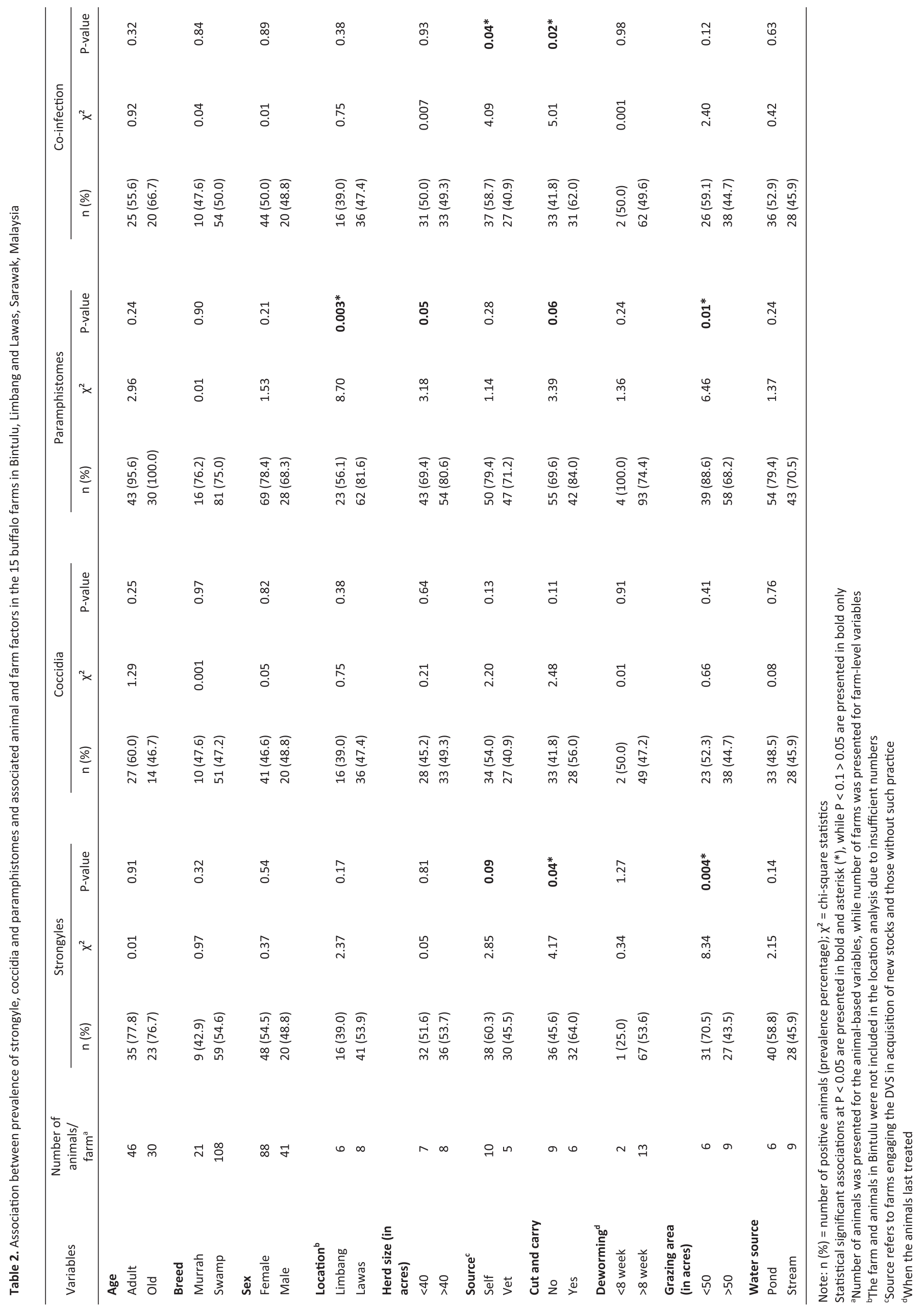


Harizt et al. (2021), Tropical Biomedicine 38(3): 318-326

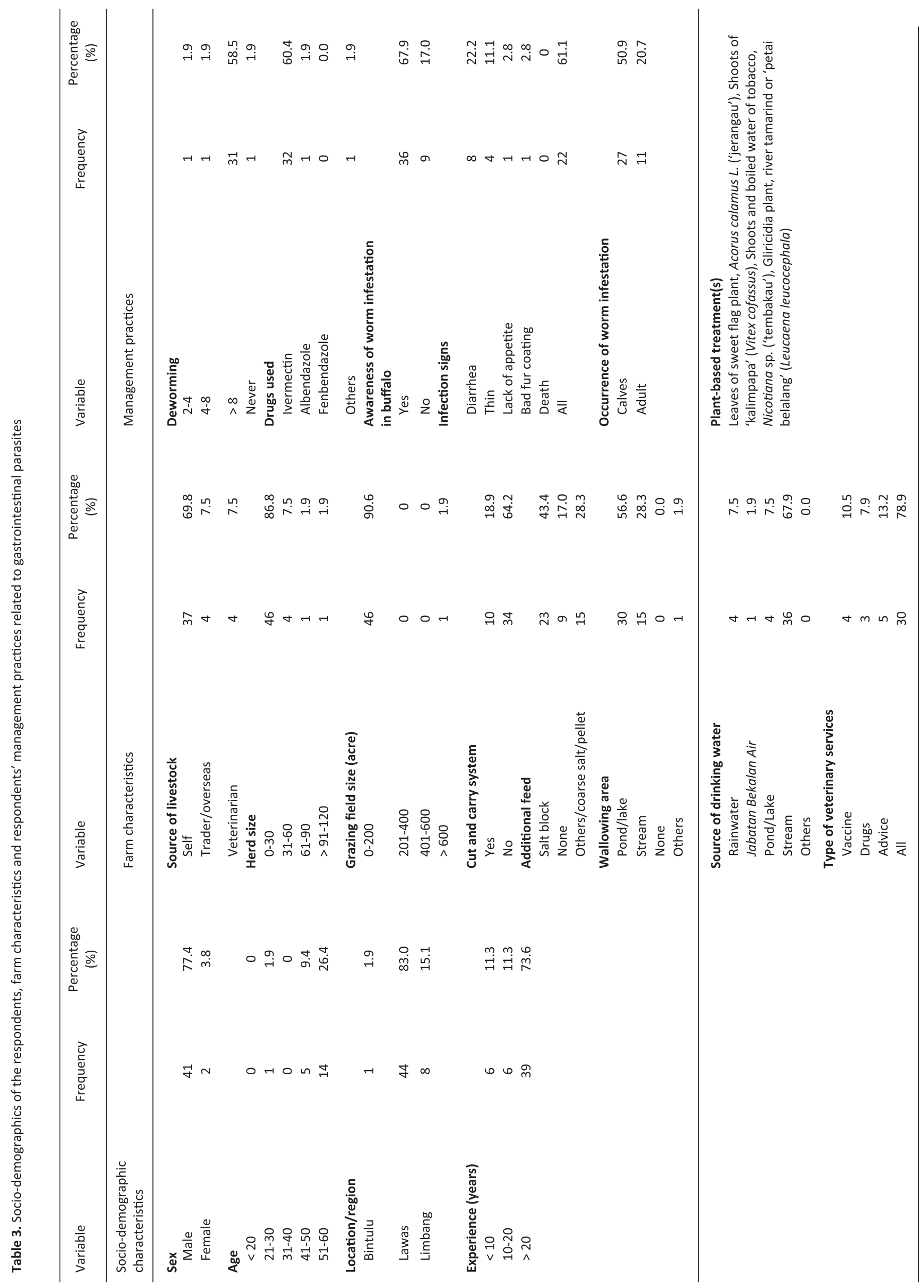


Rumen and liver fluke infections have been reported in ruminants in various farms in West Malaysia (Zainalabidin et al., 2015; Khadijah et al., 2017; Diyana et al., 2020), but reports from Borneo Island have been lacking. A lower prevalence of $\mathrm{Gl}$ parasites $(18.8 \%)$ has been reported in buffaloes and cattle from Sri Lanka (Gunathilaka et al., 2018), and $41.4 \%$ of the animals sampled in Bangladesh were positive for $P$. cervi (Bersissa et al., 2011). The egg counts for Paramphistomum sp. reported in the present study were relatively low, however, the overall prevalence was higher than that reported from other Asian countries. The current findings on FEC of strongyle and coccidia were notably lower than previous studies Bahrami and Alborzi (2013), Nath et al. (2016), and Nurhidayah et al. (2019). Our analysis of the faecal egg/oocyst counts from a total of 129 buffaloes on 15 farms detected a high number of zero counts, and the pattern of egg output did not follow a log-normal distribution pattern. It is important to remember that egg shedding is intermittent, and this limits the detection of infection via faecal sample analysis. Such distributions of zero egg counts for individual buffalo was influenced by the degree of pasture exposure and by time of sampling (Morgan et al., 2005). In cattle, for instance, the level of egg excretion is generally low and highly aggregated whereby most cattle have a low egg count in their feces although a few animals will shed a higher number of eggs (Levecke et al., 2012).

The prevalence of strongyles was higher on farms with grazing areas less than 50 acres, and in herds fed with the cut-and-carry system. The reason for these findings is not clearly understood; however, increased exposure to infection may be attributed to a higher concentration of eggs per grazing area and the density-dependent nature of the infection (Takeuchi-Storm et al., 2017). In the present study, all the animals were managed extensively and were moved in groups, grazed on the same pasture throughout the year, and used for production purposes. Contamination of feeds during the cut-and-carry process may contribute to a higher exposure to the GI parasites. Therefore, management practices may be influencing the prevalence of strongyles in the study area. It should be noted that grazing management recommendations such as pasture condition, forage quantity and quality as well as stoking density are needed to improve the nutritional status of the grazing grass. Excessive grazing will lead to certain forage folliage having inadequate regrowth time which in turn will negatively affect livestock welfare due to temporary nutritional stress. The nutritional value of grasses also plays an important part in maintaining the growth and condition of livestock. Previous studies have shown that the protein and fibre contents of 55 species of forage grasses selected from 16 countries ranged from 5 to $36 \%$ and 34 to $90 \%$, respectively (Lee et al., 2017). The authors also showed that lower quality forage grasses were found frequently in warmer areas, and they contained higher portions of fibre (Lee et al., 2017). Higher percentages of fibre are generally tougher to digest. On top of that, animals with low protein diets are more susceptible to parasite infection due to less immunoglobulin IgA-produced. Thus, mineral blocks and vitamin supplements in animal diets may be required in the studied farms (Table 3 ).

A higher prevalence of paramphistomes was seen on farms with a grazing area less than 50 hectares and on farms with more than 40 animals. Small streams were present on most of the farms, especially around the pasture and grazing areas. Such areas are ideal habitats for the freshwater snail intermediate host of Paramphistomum sp., and likely explains the prevalence of paramphistomes. Factors such as a lack of fencing (to limit buffalo wallowing activity within snail habitats) and poor biosecurity measures may also contribute to infection with paramphistomes (Charlier et al., 2011). The cut-and-carry system may also be a potential source of rumen fluke infection, and high cutting of grass is recommended to avoid contamination by metacercariae (Suhardono et al., 2006). In previous studies, it was observed that calves had a lower prevalence of Paramphistomum sp. compared to adult buffaloes (Maqbool et al., 2002; Cauquil et al., 2016). Of note, in this study, calves were not considered in the analysis because data was only available for two animals. However, the adult animals were categorized using a cut value of 5 years old $(\leq 5$ years $=$ adult, $>5$ years $=$ old $)$. Although there was no significant association between age and prevalence of each GI parasite, $100 \%$ of old buffaloes were infected with rumen flukes. Thus, this finding is consistent with previous reports showing a higher risk of rumen flukes in older buffaloes. For example, in a study from the Republic of Ireland, the prevalence of rumen fluke infection was lower in calves, which is expected based on their age and consequently shorter exposure time (Toolan et al., 2015). Further investigation is required to determine whether immunity to paramphistomes is acquired in the same way as to other GI parasites (Albuquerque et al., 2019).

The prevalence of co-infection with more than one type of parasite was significantly associated with the cut-andcarry system; poor biosecurity during the preparation of such feed may increase parasite exposure. Those farms that acquire animals themselves, rather than through the DVS, also had a higher prevalence of co-infection. This could indicate that the DVS plays a role in improving herd health management. We identified no clinical signs of parasitic diseases during our sampling visits. This highlights the importance of the identified GI parasites in subclinical infections, such infections can still result in significant economic losses (Bersissa et al., 2011). Co-infection may result in significant morbidity and reduced production in livestock (Bersissa et al., 2011). A particularly high prevalence of combined coccidia and nematode infection was seen and is recognized in other studies (Gorsich et al., 2014). This finding could be attributed to similarities in exposure, age patterns of infection, and susceptibility of the animals, rather than inter-parasitic interaction (Fenton et al., 2010). For instance, infection with coccidia and nematodes is via the faecal-oral route and involves development of infectious phases in the environment (Gorsich et al., 2014).

Although some farmers did not provide their age and gender, our study revealed that the majority of buffalo famers were male. This is in contrast to findings by Raney et al. (2011) who stated that over $40 \%$ of the agricultural labour force in the developing world is comprised of women. More than three-quarters of farmers surveyed were over 50 years old, and nearly three-quarters reported that they had more than 20 years of buffalo farming experience. This is in line with previous findings by Islam et al. (2017) who reported $53 \%$ of buffalo farmers had over 15 years' experience. It is likely that farmers' knowledge of buffalo management is based on experiences passed from generation to generation, which has implications for the future education of farmers.

There was good awareness of helminth infections in buffaloes among farmers, which may be related to their experience. However, only around fifty percent of farmers thought that GI parasite infections are more common in calves. Ivermectin was reported as the most common drug used by farmers to treat parasitic infections in buffaloes. This drug is effective at controlling the mature and immature stages of many species of GI parasites along with lungworms and insects (Dyary, 2016). We did not investigate the reason 
why most farmers preferred ivermectin, however overreliance on a single drug may influence the development of drug resistance and is worth investigating further. Despite the high prevalence of Paramphistomum sp. in the sampled buffaloes, no drugs effective against these parasites were used, however flukicide drugs are not readily available in Malaysia. As this parasite is increasingly being recognized as clinically significant (Khadijah et al., 2017; Diyana et al., 2020), this could become more important in the future.

This study is the first of its kind to investigate the prevalence and distribution of GI parasites in buffalo in Sarawak. However, our study is not without its limitations, including the small sample size and the incomplete responses from survey participants. Due to the inclusion criteria used, it may not be possible to translate our findings to those farms that did not meet the criteria. Future studies will need to address such limitations, and should also include geographical and climate factors that could also influence prevalence of GI parasites. Although we attempted larval culture (data not shown) this was unsuccessful and means that species-level identification of the strongyle parasites was not possible.

In conclusion, a high prevalence of strongyles, coccidia and paramphistomes were observed in buffaloes in the sampled farms in Bintulu, Limbang and Lawas, Sarawak. This epidemiological data will be useful in providing information on prevalence, disease control and prediction of the future trends of the diseases for effective farm management. The findings suggest that control and prevention measures should be taken to reduce GI parasitic infections among buffaloes in Borneo, Sarawak. Likewise, there is a need to improve management practices and farmers' knowledge about GI parasites affecting buffaloes in the region.

\section{ACKNOWLEDGEMENTS}

This research was funded by Universiti Putra Malaysia (Putra Grant - Putra Young Initiative, grant number GP-IPM/2016/ 9510800). The authors would like to thank the staff of DVS and buffalo farmers in Sarawak who kindly devoted their time, resources and effort throughout this study.

\section{Conflict of Interest}

The authors declare that they have no conflict of interests.

\section{REFERENCES}

Albuquerque, A.C.A., Bassetto, C.C., Almeida, F.A., Hildersley, K.A., Tom, N.M., Britton, C. \& Amarante, A.F.T. (2019). Differences in immune responses to Haemonchus contortus infection in the susceptible lle De France and the resistant Santa Ines sheep under different anthelmintic treatments regimens. Veterinary Research 50: 104. https:// doi: 10.1186/s13567-019-0722-3

Bahrami, S. \& Alborzi, A.R. (2013). Prevalence of subclinical coccidiosis in river buffalo calves of southwest of Iran. Acta Parasitologica 58: 527-530. https://doi.org/10.2478/ s11686-013-0167-1

Basripuzi, H.B., Sani, R.A. \& Ariff, O.M. (2012). Anthelmintic resistance in selected goat farms in Kelantan. Malaysian Journal of Animal Science 15: 47-56.

Bersissa, K., Tigist, T., Teshale, S., Reta, D. \& Bedru, H. (2011). Helminths of sheep and goats in central Oromia (Ethiopia) during the dry season. Journal of Animal and Veterinary Advances 10: 1845-1849. https://doi.org/10.3923/ javaa.2011.1845.1849
Cauquil, L., Hüe, T., Hurlin, J.C., Mitchell, G., Searle, K., Skuce, P. \& Zadoks, R. (2016). Prevalence and sequence-based identity of rumen fluke in cattle and deer in New Caledonia. PLoS One 11: e0152603. https://doi.org/10.1371/ journal.pone.0152603

Chandrawathani, P., Nurulaini, R., Adnan, M., Premalaatha, B., Khadijah, S., Jamnah, O., Zaini, C.M., Khor, S.K. \& Zawida, Z. (2009). A survey of parasitic infection on small ruminant farms in Kinta and Hilir Perak districts, Perak, Malaysia. Tropical Biomedicine 26: 11-15.

Charlier, J., Bennema, S.C., Caron, Y., Counotte, M., Ducheyne, E., Hendrickx, G. \& Vercruysse, J. (2011). Towards assessing fine-scale indicators for the spatial transmission risk of Fasciola hepatica in cattle. Geospatial Health 2: 239-245. https://doi.org/10.4081/gh.2011.176

Das, M., Deka, D.K., Sarmah, A.K., Sarmah, P.C. \& Islam, S. (2018). Gastrointestinal parasitic infections in cattle and swamp buffalo of Guwahati, Assam, India. Indian Journal of Animal Research 52: 1732-1738. https://doi.org/10.18805/ijar.B-3427

Diyana, J., Mahiza, M.I., Latiffah, H., Fazila, S.H., Lokman, I.H., Hazfalinda, H.N., Chandrawathani, P., Ibitoye, E.B. \& Juriah, K. (2020). Occurrence, morphometric, and molecular investigation of cattle and buffalo liver adult fluke in Peninsular Malaysia main abattoirs. Journal of Parasitology Research 2020: 1-6. https://doi.org/10.1155/2020/5436846

Dorny, P., Devleesschauwer, B., Stoliaroff, V., Sothy, M., Chea, R., Chea, B., Sourloing, H., Samuth, S., Kong, S., Nguong, K. et al. (2015). Prevalence and associated risk factors of Toxocara vitulorum infections in buffalo and cattle calves in three provinces of central Cambodia. The Korean Journal of Parasitology 53: 197-200. https://doi.org/10.3347/kjp. 2015.53.2.197

Dyary, H.O. (2016). Veterinary anthelmintics and anthelmintic drug resistance. Journal of Zankoy Sulaimani. Part-A (Pure and Applied Sciences) 18: 191-206. https://doi.org/10.17656/ jzs.10463

Ezenwa, V.O. \& Jolles, A.E. (2008). Horns honestly advertise parasite infection in male and female African buffalo. Animal Behaviour 75: 2013-2021. https://doi.org/10.1016/ j.anbehav.2007.12.013

Fenton, A., Viney, M.E. \& Lello, J. (2010). Detecting interspecific macroparasite interactions from ecological data: patterns and process. Ecology Letters 13: 606-615. https://doi.org/ 10.1111/j.1461-0248.2010.01458.x

Gorsich, E.E., Ezenwa, V.O. \& Jolles, A.E. (2014). Nematodecoccidia parasite co-infections in African buffalo: Epidemiology and associations with host condition and pregnancy. International Journal for Parasitology: Parasites and Wildlife 3: 124-134. https://doi.org/10.1016/j.ijppaw. 2014.05.003

Graham-Brown, J., Hartley, C., Clough, H., Kadioglu, A., Baylis, M. \& Williams, D.J.L. (2018). Dairy heifers naturally exposed to Fasciola hepatica develop a type 2 immune response and concomitant suppression of leukocyte proliferation. Infection and Immunity 86: e00247-18. https:/ /doi.org/10.1128/IAI.00607-17

Gunathilaka, N., Niroshana, D., Amarasinghe, D. \& Udayanga, L. (2018). Prevalence of gastrointestinal parasitic infections and assessment of deworming program among cattle and buffaloes in Gampaha District, Sri Lanka. BioMed Research International 2018: 3048373. https://doi.org/ $10.1155 / 2018 / 3048373$

Hoste, H., Sotiraki, S., Landau, S.Y., Jackson, F. \& Beveridge, I. (2010). Goat-nematode interactions: think differently. Trends in Parasitology 26: 376-381. https://doi.org/10.1016/ j.pt.2010.04.007 
Islam, S., Nahar, T.N., Begum, J., Deb, G.K., Khatun, M. \& Mustafa, A. (2017). Economic evaluation of buffalo production in selected regions of Bangladesh. Journal of Stock \& Forex Trading 5: 3. https://doi.org/10.4172/21689458.1000177

Jolles, A.E., Ezenwa, V.O., Etienne, R.S., Turner, W.C. \& Olff, H. (2008). Interactions between macroparasites and microparasites drive infection patterns in free ranging African buffalo. Ecology 89: 2239-2250. http://dx.doi.org/ 10.1890/07-0995.1

Kamaludeen, J. (2010). Dissertation: Studies on the occurrence of anthelmintic resistance in goat parasites in New Zealand. Massey University.

Kamaludeen, J., Graham Brown, J., Stephens, N., Miller, J., Howell, A., Beesley, N.J., Hodgkinson, J., Learmount, J. \& Williams, D. (2019). Lack of efficacy of triclabendazole against Fasciola hepatica is present on sheep farms in three regions of England, and Wales. Veterinary Record 184: 502-502. https://doi.org/10.1136/vr.105209

Karim, W., Farajallah, A. \& Suryobroto, B. (2016). Exploration and prevalence of gastrointestinal worm in buffalo from West Java, Central Java, East Java and Lombok, Indonesia. Aceh Journal of Animal Science 1: 1-15. https://doi.org/ 10.13170/ajas.1.1.3566

Khadijah, S., Ariff, Z., Nurlaili, M.R., Sakiinah, A., Izzudin, A.H., Mursyidah, A.K., Rita, N. \& Nur Aida, H. (2017). Fasciola and Paramphistomum infection in large ruminants. International Journal of Agronomy and Agricultural Research 10: $19-26$

Lee, M., Davis, A., Chagunda, M. \& Manning, P. (2017). Forage quality declines with rising temperatures, with implications for livestock production and methane emissions. Biogeosciences Discussions 14: 1403-1417. https://doi.org/ 10.5194/bg-2016-389

Levecke, B., Dobson, R.J., Speybroeck, N., Vercruysse, J. \& Charlier J. (2012). Novel insights in the faecal egg count reduction test for monitoring drug efficacy against gastrointestinal nematodes of veterinary importance. Veterinary Parasitology 188: 391-396. https://doi.org/ 10.1016/j.vetpar.2012.03.020

Malik, S.I., Afshan, K. \& Qayyum, M. (2017). Phenotyping of amphistomes, and pathological, hematological and bile biochemical response to Gigantocotyle explanatum infection in buffaloes. Pakistan Journal of Zoology 49: 979987. https://dx.doi.org/10.17582/journal.pjz/2017.49.3. 979.987

Maqbool, A., Sikandar Hayat, C., Akhtar, T. \& Hashmi, H.A. (2002). Epidemiology of fasciolosis in buffaloes under different managemental conditions. Veterinarski Arhiv 72: 221-228.

Moço, G., Serrano, E., Guerreiro, M., Ferreira, A.F., PetrucciFonseca, F., Santana, D., Joao Maia, M., Soriguer R.C. \& Pérez, J.M. (2014). Does livestock influence the diet of Iberian ibex Capra pyrenaica in the Peneda-Gerês National Park (Portugal)? Mammalia 78: 393-399. https://doi.org/ 10.1515/mammalia-2013-0139

Morgan, E.R., Cavill, L., Curry, G.E., Wood, R.M. \& Mitchell, E.S.E. (2005). Effects of aggregation and sample size on composite faecal egg counts in sheep. Veterinary Parasitology 131: 79-87. https://doi.org/10.1016/j.vetpar.2005.04.021
Nath, S., Das, G., Dixit, A.K., Agrawal, V., Singh, A.K., Kumar, S. \& Katuri, R.N. (2016). Epidemiological studies on gastrointestinal parasites of buffaloes in seven agro-climatic zones of Madhya Pradesh, India. Buffalo Bulletin 35: 355364.

NorAzlina, A.A., Sani, R.A. \& Ariff, O.M. (2011). Management practices affecting helminthiasis in goats. Pertanika Journal of Tropical Agricultural Science 34: 295-301.

Nurhidayah, N., Satrija, F. \& Retnani, E.B. (2019). Gastrointestinal parasitic infection of swamp buffalo in Banten Province, Indonesia: Prevalence, risk factor, and its impact on production performance. Tropical Animal Science Journal 42: 6-12. https://doi.org/10.5398/tasj.2019.42.1.6

Raney, T., Anríquez, G., Croppenstedt, A., Gerosa, S., Lowder, S.K., Matuschke, I. \& Skoet, J. (2011). The role of women in agriculture (ESA Working Papers 289018). Food and Agriculture Organization of the United Nations, Agricultural Development Economics Division (ESA). https:// doi.org/10.22004/ag.econ.289018

Raza, M.A., Iqbal, Z., Jabbar, A. \& Yaseen, M. (2007). Point prevalence of gastrointestinal helminthiasis in ruminants in southern Punjab, Pakistan. Journal of Helminthology 81: 323-328. https://doi.org/10.1017/S0022149X07818554

Rohaya, M.A., Tuba Thabitah, A.T., Asmah, K.S., Azzura, L., Chandrawathani, P., Kasmah, S. \& Saipul Bahari, A.R. (2017). Common blood parasites diagnosed in ruminants from 2011 to 2015 at the central veterinary laboratory, Sepang, Malaysia. Malaysian Journal of Veterinary Research 8: 163167.

Stewart, C.G. \& Penzhorn, B.L. (2004). Infectious diseases of livestock. 2nd edition. Cape Town: Oxford University Press. https://doi.org/10.4102/jsava.v76i4.435

Suhardono, R.J. \& Copeman, D. (2006). The effect of temperature and humidity on longevity of metacercariae of Fasciola gigantica. Tropical Animal Health and Production 38: 371-377. https://doi.org/10.1007/s11250-006-4310-y

Takeuchi-Storm, N., Denwood, M., Hansen, T.V.A., Halasa, T., Rattenborg, E., Boes, J., Enemark, H.L. \& Thamsborg, S.M. (2017). Farm-level risk factors for Fasciola hepatica infection in Danish dairy cattle as evaluated by two diagnostic methods. Parasites \& Vectors 10: 555. https://doi.org/ 10.1186/s13071-017-2504-y

Toolan, D.P., Mitchell, G., Searle, K., Sheehan, M., Skuce, P.J. \& Zadoks, R.N. (2015). Bovine and ovine rumen fluke in Ireland - Prevalence, risk factors and species identity based on passive veterinary surveillance and abattoir findings. Veterinary Parasitology 212: 168-174. https:// doi.org/10.1073/pnas.2013102117

Zainalabidin, F.A., Azmi, M.S.N.N., Bakri, W.N.W.O., Sathaya, G. \& Ismail, M.I. (2015). Screening for zoonotic fascioliasis in slaughtered large ruminants in abattoirs in Perak, Malaysia. Tropical Life Sciences Research 26: 121-124.

Zhang, J.L., Si, H.F., Zhou, X.Z., Shang, X.F., Li, B. \& Zhang, J.Y. (2019). High prevalence of fasciolosis and evaluation of the efficacy of anthelmintics against Fasciola hepatica in buffaloes in Guangxi, China. International Journal for Parasitology: Parasites and Wildlife 8: 82-87. https://doi.org/ 10.1016/j.ijppaw.2018.12.0 